\title{
Correction to: The history of the purine Club: a tribute to prof. Geoffrey Burnstock
}

\author{
Maria P. Abbracchio ${ }^{1}$ \\ Published online: 13 April 2021 \\ (C) Springer Nature B.V. 2021
}

\section{Correction to: Purinergic Signalling (2021) 17:127-134 https://doi.org/10.1007/s11302-020-09749-4}

I unwittingly forgot to mention the Purines 2018 meeting held in Brazil in the list of the Purines meetings reported on page 129:

Original list of Purines meetings:

Purines 1996 (Milan, Italy)

Purines 1998 (Ferrara, Italy)

Purines 2000 (Madrid, Spain)

Purines 2002 (Gold Coast, Australia)

Purines 2004 (Chapel Hill, USA)

Purines 2006 (Ferrara, Italy)

Purines 2008 (Copenhagen, Denmark)

Purines 2010 (Tarragona, Spain)

Purines 2012 (Fukuoka, Japan)

Purines 2014 (Bonn, Germany)

Purines 2016 (Vancouver, Canada)

Purines 2019 (Santiago de Compostela, Spain) that also coincided with the First European Purine Meeting

The list is replaced with the correct one:
Corrected list of Purines meetings:

Purines 1996 (Milan, Italy)

Purines 1998 (Ferrara, Italy)

Purines 2000 (Madrid, Spain)

Purines 2002 (Gold Coast, Australia)

Purines 2004 (Chapel Hill, USA)

Purines 2006 (Ferrara, Italy)

Purines 2008 (Copenhagen, Denmark)

Purines 2010 (Tarragona, Spain)

Purines 2012 (Fukuoka, Japan)

Purines 2014 (Bonn, Germany)

Purines 2016 (Vancouver, Canada)

Purines 2018 (Foz do Iguaçu, Brazil)

Purines 2019 (Santiago de Compostela, Spain) that also coincided with the First European Purine Meeting

Finally, I apologize for any confusion this may cause.

Publisher's note Springer Nature remains neutral with regard to jurisdictional claims in published maps and institutional affiliations.

The online version of the original article can be found at https://doi.org/ 10.1007/s11302-020-09749-4

Maria P. Abbracchio

mariapia.abbracchio@unimi.it

1 Department of Pharmaceutical Sciences, University of Milan, Via Balzaretti 9, 20133 Milan, Italy 